\title{
Education's Impact on the Decline of Craft Workers in the United States Construction Industry
}

\author{
Scott W. Kramer, Carol Jayroe and April E. Simons
}

Auburn University, Auburn, Alabama, USA

\begin{abstract}
As the number of craft workers in the United States has declined significantly in the past 20 years, various news articles and studies cite multiple reasons that have led to the decline. Perhaps the most significant impact is the evolution of technology. As technology has evolved, younger generations have not been exposed to the same opportunities as their parents and grandparents; therefore, they have not developed hands-on skills, causing a lack of interest in craft labor from an early age. If today's generation is not acquiring interests in these skills during their own time, has America's educational systems responded to this change by strengthening their vocational programs to maintain interest from the younger generation? For this study, data provided by the National Center for Education Statistics (NCES) was analyzed to determine the availability and interest in construction trade programs throughout the United States, to conclude if educational opportunities have impacted the recent decline in the construction trades.
\end{abstract}

(c) 2020 The Authors. Published by Budapest University of Technology and Economics \& Diamond Congress Ltd Peer-review under responsibility of the Scientific Committee of the Creative Construction Conference 2020.

Keywords: career, and technical education (CTE), higher education, occupational, vocational

\section{Introduction}

The craft/skilled trade worker labor category is extremely broad; it includes higher skilled occupations in construction (building trades, craft workers, and their formal apprentices), natural resource extraction workers, occupations related to the installation, maintenance and part replacement of equipment machines and tools, and also production occupations (Code of Federal Regulations, 2017).

Unfortunately, the construction industry has experienced a nationwide shortage of skilled labor. Construction is the second largest employer in the country and according to a recent study performed by the Construction Industry Institute, $75 \%$ of contractors are experiencing labor shortages that are resulting in cost overruns and/or schedule delays (Christine Fiori, 2003). Upon analysis of why there is a decline in the number of workers, there are many possible explanations; however, the most significant factor is simply that the younger generation is not replacing the older generation at the rate at which they are leaving the industry. 


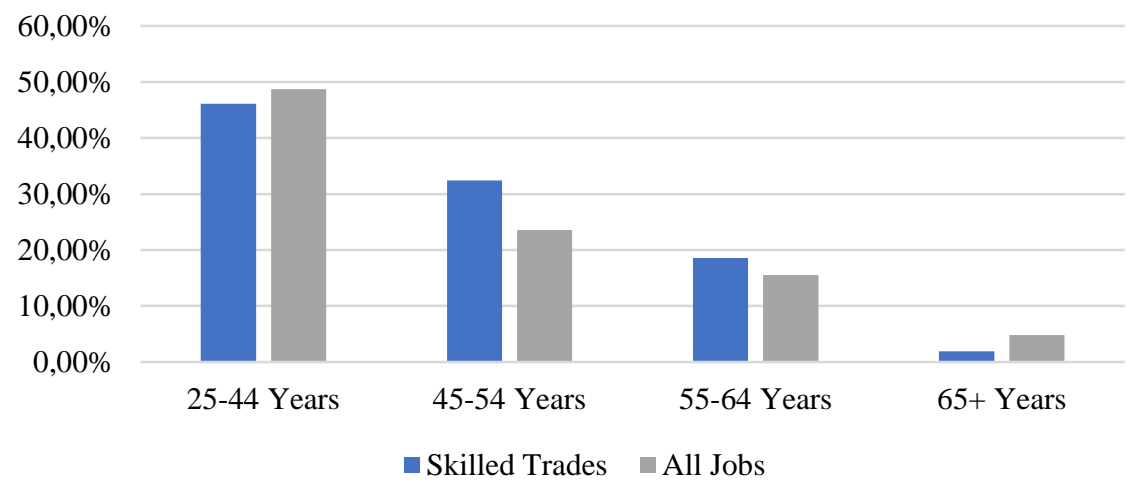

Figure 1. Age Breakdown: Skilled Trades vs. All Jobs (Wright, 2013)

According to EMSI (Economic Modeling Specialists International), in 2012, 53\% of skilled-trade workers in the United States were 45 years and older and $18.6 \%$ were between the ages of 55 and 64 . In comparison, $44 \%$ of workers were 45 years and older and $15.5 \%$ were between the ages of 55 and 64 . A more significant statistic is that skilled-trades have only $1.9 \%$ of workers 65 and older, whereas the total labor force has $4.8 \%$ (Wright, 2013). Unfortunately, these numbers allude that older skilled-trade-workers are often not able to avoid an early retirement due to physical ailments, as their jobs are more physically demanding than a typical white-collar job. As a result of earlier retirements from the current workforce, there is more pressure for the younger workforce to replace them at a faster rate.

Another possible explanation for the decline in skilled labor trade could be the lack of interest and negative perception of the industry from the younger generations. When surveyed about possible career choices, high school students ranked a career as a construction worker 247 out of 250 occupation options (Bigelow, Ostadalimakhalbaf, \& Escamilla, 2016). Unfortunately, many view the construction industry as undesirable because of the high job intensity, dangerous and dirty working environments, and ambiguous career paths. This is unfortunate, as the construction industry is evolving and working to overcome this perception by implementing strict safety programs and offering new programs to improve craft worker's physical health such as regulation health examinations, health guidance, smoking cessation measures, and nutritional education (Shan, Ph.D., P.E., M.ASCE, Imran, Lewis, Ph.D., P.E., M.ASCE, \& Zhai, Ph.D., 2017).

The negative perception of the construction industry is a result of the United States' education system. Unfortunately, the past two generations have been encouraged by American high schools to attend a fouryear college, promising more employment opportunities and a greater salary potential. However, as more people are seeking college degrees, many are finding that a degree doesn't necessarily provide employment in high paying positions. In order to meet the growing demand of the construction industry, education systems across the United States must emphasize the high and growing demand for construction trade workers, the significance of the industry to our economy, and encourage America's youth to return to the construction industry (The Construction Labor Shortage: Where Did All the Skilled Labor Go?, 2017).

To change the perception of the industry, the United States should look nations like Germany, where craft work is regarded not as merely a trade, but a career, with schools offering apprenticeship programs for high school students. Richard Sennett, a New York University sociologist states, "Corporations in Germany realized that there was an interest to be served economically and patriotically in building up a skilled labor force at home; we never had that ethos" (Uchitelle, 2012).

\section{Background}

The Smith-Hughes Act of 1917 was the first authorization for the Federal funding of vocational education. Subsequent legislation for vocational education (now termed career and technical education) included the Vocational Act of 1973. The Carl D. Perkins Career and Technical Education Improvement Act was initially authorized in 1984 and re-authorized in 1990, 1998 and 2006 (Smith-Hughes Act, 2003). On May 17, 2017, the House Education and the Workforce Committee unanimously approved its Perkins reauthorization bill, H.R. 2353, the Strengthening Career and Technical Education for the 21st Century Act (Hyslop, 2017). 
The Perkins Act provides almost $\$ 1.3$ billion annually to career and technical education programs in all 50 states until 2016. Federal funds provide the principal source for innovation and program improvement. State and local funding supports the career and technical education infrastructure and pays teachers' salaries and other operating expenses (Smith-Hughes Act, 2003; Issue Brief Carl D. Perkins Act, 2017). Overall, the program's purpose is to increase the quality of technical education programs throughout the United States, providing both academic and technical skills in order to create successful workers in a knowledge-based and skill-based economy (Hyslop, 2017).

\section{Purpose of the study}

The purpose of this study is to explore what construction trade focused/vocational/occupation trade programs are being provided for the current generation. More specifically, at what age level are construction-related vocational programs being offered and discussed as a potential career pathway with students, what types of programs are being offered, and are students interested and enrolling in these programs? While vocational educational opportunities and support in schools may not be the only factor that contributes to the overall decline in skilled trade labor, it is a significant factor, as it allows all students the opportunity to be exposed to and try a variety of skilled trades. Furthermore, school counselors' encouragement and support for these programs provides students that are not interested in a four-year university or seeking a white-collar profession with a career pathway that will allow them to become an expert in whatever skilled trade that may best suit their interests.

\section{Rational for the study}

There is a substantial need for Technical Programs in schools, specifically within the construction trade industries. Based on current market needs, without school intervention, the craft worker and trades will not have enough labor support. Unfortunately, as a result, contractors will experience project labor shortages and cost escalation, lengthening of schedules and recordable incidents

Furthermore, it is the responsibility of educational programs to utilize funding for these programs and be dynamic in making sure that the future workforce is not being funneled down a four-year college preparatory career, but is instead supporting youth to explore various learning opportunities, include Career Technical Educational Programs. Statistics prove that high school students involved in CTE programs are more engaged, perform better, and graduate at higher rates. The average high school graduation rate for students in CTE programs in $90.18 \%$ compared to an average national freshman graduation rate of 74.9\% (H.R.2353 - Strengthening Career and Technical Education for the 21st Century Act).

Mr. Paul Tse, Project Manager at Shapiro \& Duncan cites how a local career and technical education program at Thomas Edison High School of Technology not only provided him with a sense of direction. Moving to America from Hong Kong at the age of 10, Mr. Tse lacked direction in his life and career, and upon the advice of a guidance counselor, enrolled in a HVAC program his senior year of high school. Upon graduation, he had two (2) job offers for an apprenticeship from local companies (H.R.2353 - Strengthening Career and Technical Education for the 21st Century Act).

Skylar Huggett, the 2017 recipient of the Georgia Occupational Award of Leadership (GOAL) scholarship was on the career path to be a nurse, at a four-year college. She soon realized that was not the right fit for her and she transferred to a community college to pursue an associates degree. Inspired by a documentary of a woman welder, she enrolled in welding classes at the earliest opportunity and realized after the first day of classes that this was a "career - something she was passionate about and truly enjoyed." As a "fouryear college" drop-out, she cites that pursuing a vocational career was something that she didn't initially consider. However, she quickly realized that it was the right fit for her, and has encouraged friends that finished college with degrees and who are unemployed or who are unsure if it is the right fit to pursue vocational classes. She states, "Had I started with technical school I wouldn't have the student debt that I do and would already have been years into my career. Vocational schools and trades need to be promoted and supported more." As a welder, she is very much aware of the decline in the workforce: "The people currently in the workforce are getting closer to retirement and there are less younger individuals entering the trades. This is a huge problem, as the experienced men and women in these are needed to pass on 
their way of the trade or the tricks and secrets to successfully get a job efficiently done. I am personally seeing a generational gap in my welding field and it's a problem." (Huggett, 2017)

\section{Research design}

The National Center for Education Statistics' (NCES) reporting system for national information on career and technical education (CTE) (Career and Technical Education) provides data based on a compilation of information from a variety of existing federal data collections. The wide variety of data sources provides an accurate overview of current statistics, as well as historical trends, and prediction models (National Center for Education Statistics, n.d.).

By utilizing CTE statistics, I am hoping to determine not only the availability of construction trade programs in high schools/vocational schools and vocational colleges, but also students' interest and participation in vocational/occupational construction trade programs in the past decade. By analyzing the statistics and exploring relationships between related figures, I will be able to determine the presence of any significant correlation between the availability and interest in vocational education programs to determine if this has contributed towards the decline in craft workers.

\section{Data and analysis}

\section{CTE Programs, Secondary Education}

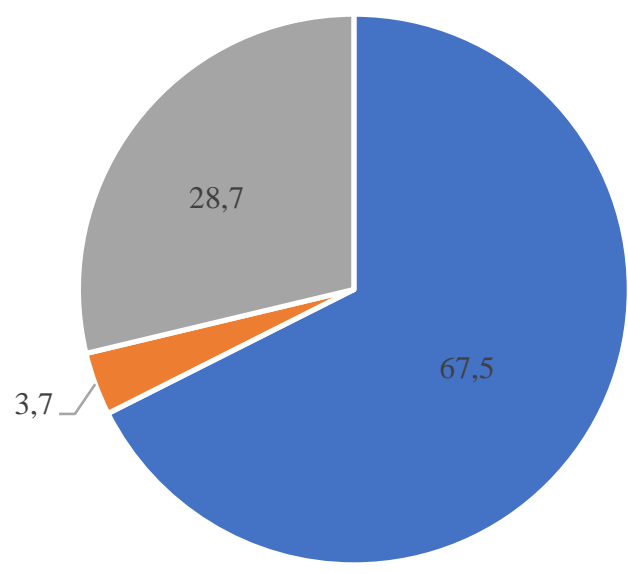

- Regular high school = Career/ technical high school = Other special focus high school*

Figure 2. Percentage of public high schools that are regular, career/technical, and other special focus, and various characteristics of each school type: 2008, (National Center for Education Statistics, n.d.).

According to the U.S. Department of Education, National Center for Education Statistics, Schools, and Staffing Survey (SASS) Public School Questionnaire, for the school year 2007-2008, approximately sixty-eight (68) percent of public high schools were "regular" high schools, meaning that vocational programs may be offered as elective classes for students, but the overall curriculum was not "vocationally" driven, but was based on a standard teaching curriculum. Approximately twenty-eight (28) percent are considered "other special focus high schools" such as science or mathematics schools, performing arts schools, talented or gifted schools, and foreign language immersion schools), special education schools, alternative schools, and other types of schools that do not fall into these categories. Nevertheless, only four (4) percent are considered "career/technical" high schools (National Center for Education Statistics, n.d.).

Recognizing the growing demand for vocational trade, the Perkins Vocational and Technical Act has funded several new Career/Technical high schools in North Carolina, specifically. In Wilmington, the first Career and Technical Education high school will be opening in the Fall of 2017 (DelaCourt, 2016). This school was modeled after the Vernon Malone College and Career Academy in Wake County, North Carolina, which 
opened in August 2014. Due to the success of the Vernon Malone College, the North Wake College and Career Academy was opened in September 2016. While this is limited to the piedmont/coast of North Carolina's educational system, school systems around the United States are recognizing not only the need for these programs, but their success and contribution to not only providing students with education and career paths, but matching students with career paths that are in high demand by industry (Wake County names new CTE high school and hires its principal, 2016).

Table 1:Percentage of public high schools offering various occupational preparation opportunities

\begin{tabular}{|l|c|c|c|}
\hline & $\begin{array}{c}\text { Regular High } \\
\text { School }\end{array}$ & $\begin{array}{c}\text { Career/Technical } \\
\text { High School }\end{array}$ & $\begin{array}{c}\text { Other Special } \\
\text { Focus High } \\
\text { School }\end{array}$ \\
\hline Career/Technical Education Courses & $93.6 \%$ & $100 \%$ & $55.1 \%$ \\
\hline $\begin{array}{l}\text { Work-based Learning or Internships Outside of } \\
\text { School }\end{array}$ & $70.6 \%$ & $79 \%$ & $51.5 \%$ \\
\hline Specialized Career Academy & $26.7 \%$ & $61 \%$ & $13.2 \%$ \\
\hline
\end{tabular}

(National Center for Education Statistics, n.d.)

While many school systems are recognizing the need for career/technical high schools, the vocational education system is not lost in the "traditional" or "regular" high school curriculum. As seen in table 1, in ninety-four (94\%) of regular high schools across the United States offer career/technical courses. It is important not to overlook the importance of offering vocational courses to students. Often, many students may consider a vocational course just as an elective, but by merely giving students an opportunity to be exposed to trades, schools are allowing students to be exposed to different career paths. These "traditional" vocational classes are extremely valuable and allow students exposure and appreciation of trades without having to formally commit to that career pathway. Therefore, it is important to realize that while Career/Technical high schools may provide educational opportunities to students who are interested in committing themselves to vocational/trade career paths, regular high schools offering career/technical courses are equally as important, as they provide the "traditional" or four-year college pathway students with exposure to the trades, without formal commitment (National Center for Education Statistics, n.d.).

The data also demonstrates that there is not a significant difference between the percentage of internships available outside of school in "traditional" high schools compared to career/technical high schools. This is extremely important, as apprenticeships offer students the ability to not only learn more about a trade but the opportunity to build their confidence in their future and to see how this trade could provide them with opportunities to shape their career. Nancy Hoffman, the author of Schooling in the Workplace, states that the United States' vocational education program is falling behind its European Counterparts. The unemployment rate in the Netherlands and Switzerland is (5\%) compared to the United States' twenty-two (22\%). Ms. Hoffman cites that the "forgotten half" of students (between the age of 16 to 22) who will not attend a four-year college will be at risk of trying not to land in jail, be unemployed and living on the street, or eternally job-hopping. By allowing students to participate in apprenticeship programs you allow students to enter the workforce and instill responsibilities that allow them to gain confidence in their trade and provide experience that will prepare them to enter the industry immediately following graduation (Goldstein, 2012).

Apprenticeship programs are vital components of all vocational programs. However, part of the challenge in providing apprenticeship opportunities is overcoming the perspective of many Americans that most sixteen (16) year-olds are not ready for the responsibility of learning a trade. In her book Schooling the Workplace, Ms. Hoffman mentions that Volkswagen is starting an European-style apprenticeship program in Tennessee, but it is only available to high school graduates. Ms. Hoffman also suggests that the United States should look towards Switzerland for the implementation of apprenticeship programs. The Swiss government invests in the in initial analysis of workplace training for apprenticeship hosts, and supports research between employers and government. Unlike Switzerland, there are only a small amount of institutions or non-profits in the United States that provide these services (Goldstein, 2012). 


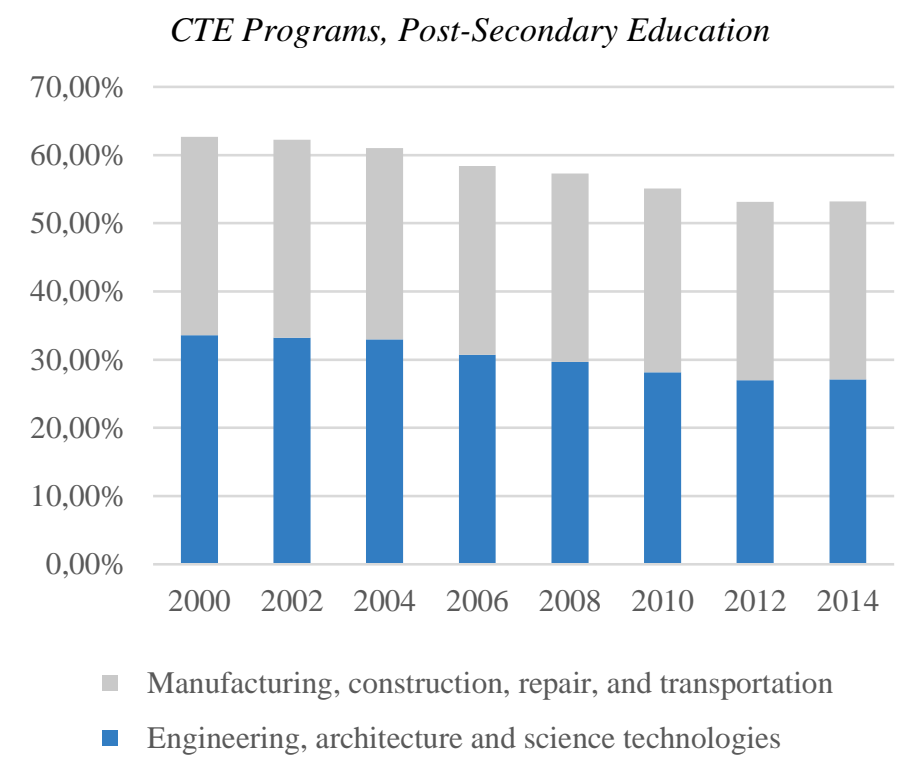

Figure 3. Percentage of post-secondary institutions that offer sub-baccalaureate occupational education programs (National Center for Education Statistics, n.d.)

While many students may enter vocational career programs in high school, often they are first exposed to vocational careers in post-secondary education programs, as they offer more diversity than the subbaccalaureate programs. Therefore, students are often are able to determine a trade that is the best fit for their interests and career aspirations. Throughout the past decade, there has been a decline in the number of sub-baccalaureate programs offered in vocational schools, as seen in Figure 2. Typically, Career Technical Education (CTE) programs are offered based on student enrollment in previous years. It is evident that the 2008 Housing Market Crash had somewhat of an impact as the enrollment in engineering, architecture and science technologies fell three (3) percent from 2008 to 2012. During that same time period, the enrollment in Manufacturing, construction, repair, and transportation fell approximately one (1) percent, from twentyseven (27) percent to twenty-six (26) percent (National Center for Education Statistics, n.d.).

While the decline between the years may not seem significant, a one (1) percent decrease in the overall enrollment of twenty-six percent is significant when it reflects to a statistic that is applied based on participation in these programs across the United States. Nevertheless, industry's growing demand for this trade has created a large push for support from sub-baccalaureates vocational programs throughout the United States, providing scholarships and supporting educational programs with apprenticeship programs. Mr. Jonathan Begue, the Construction Management Program Director at Cape Fear Community College in Wilmington, North Carolina, cited that as the local housing market has picked up following the 2008 crash, there has been a large outcry by local construction firms and the local Homebuilding Association as to why there are so little interest in the construction management/construction trade programs. Mr. Begue cites that while there was a decline following 2008, enrollment in these programs has been somewhat steady in the recent years (Begue, 2017). 


\section{CTE Programs, Interest/Enrollment - Post-Secondary Education}

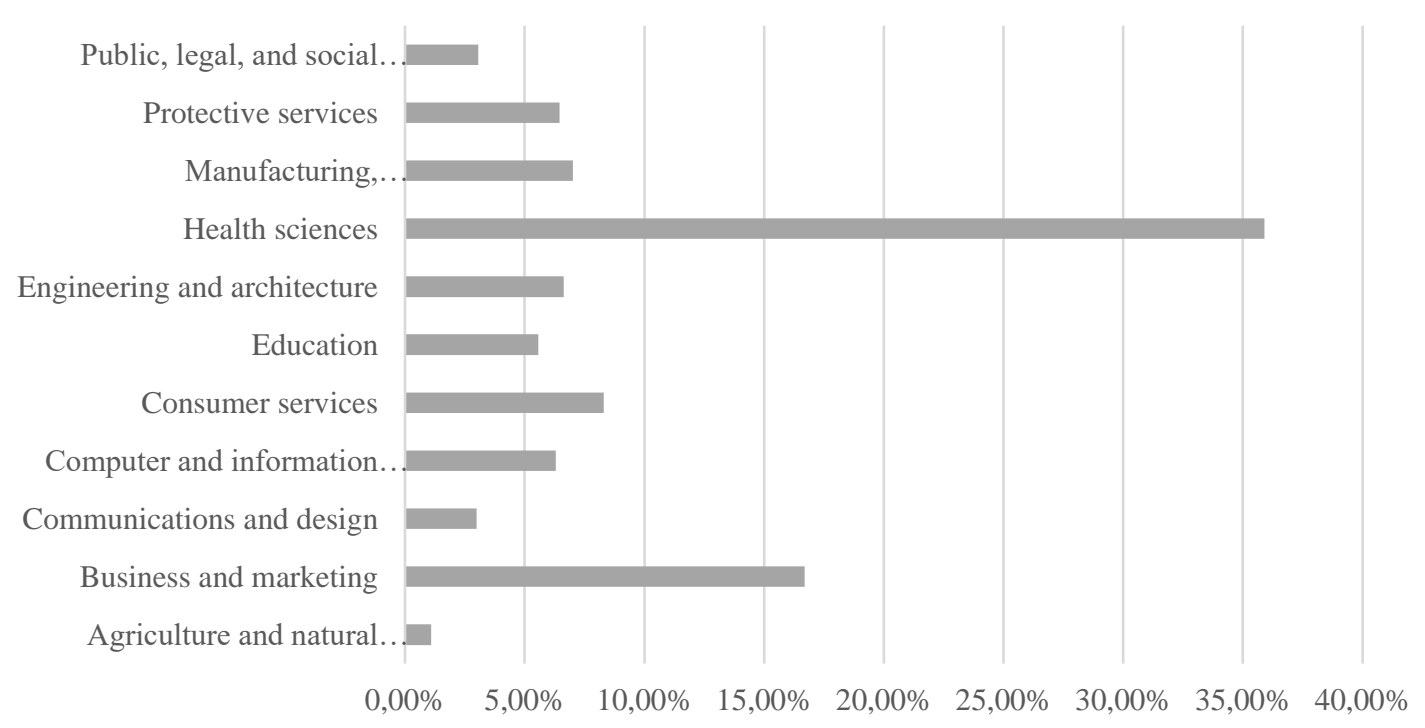

Figure 4. Percentage distribution of credential-seeking, sub-baccalaureate occupational education students within each field of study, in all institution types (National Center for Education Statistics, n.d.)

Perhaps the most obvious question in this research is if students are enrolling in construction trade programs, what other programs are appealing to vocational students? And if students are not entering construction trade programs, why are they choosing these other programs? Mr. Begue began working in the construction industry as a teenager, and speaks from first-hand knowledge of the industry; unfortunately, it comes down to one thing: wages (Begue, 2017).

According to the Bureau of Labor, the median hourly salary of a construction trade worker is $\$ 22.88$ and the annual mean wage is $\$ 47,580$. In comparison, the median hourly salary for a Registered Nurse is $\$ 32.91$ and the annual mean wage is $\$ 72,180$ (National Occupational Employment and Wage Estimates United States - May 2016, 2017). While each state has prevailing wage rates for each specialized trade, there is still a significant variance in wages between jobs. Another issue for many skilled trade workers is benefits. Compensation packages often do not include benefits such as insurance and health care. Far from a whitecollar office setting there is the threat of unsafe working conditions and injuries on a construction job site; in addition, the construction market is relative to a good financial market. The real estate crash of 2008 was a difficult time for many skilled trade professionals, who were forced to leave the industry in order to find work.

Mr. Begue acknowledges that the construction market is difficult. While many companies are now implementing stricter safety policies and procedures, and the real estate market has leveled out, students looking for career options must consider the negatives and the positives. While there has been a decline in the construction trade industry, it is difficult to convince students looking for new career opportunities to take a risk in a volatile industry without receiving competitive pay, to supplement workers who must provide their own benefits. It's an industry that has its booming times, but also has difficult times as well. Mr. Begue stresses to students that while there are negatives with every job, construction trades are unique in that you can provide your own services, your own abilities towards a final project. The satisfaction out of knowing that you are physically contributing your talents and skills towards a final goal makes provides satisfaction that is not captured in data, but captured by those who are driven to see their hard work, their creativity, and their skills produce items that are part of a larger concept. This is something that is not service - it's a trade, a skill that you have not only received education and training to practice, but something that you are so passionate about, that it's what you have chosen as your career (Begue, 2017). 


\section{Conclusion}

Based on the data, it can be determined that the education system in the United States has responded to the decline in construction trade workers by offering more vocational career programs in high schools. As more vocational trade high schools open throughout the country, it is obvious that schools are not only interested creating more opportunities for students, but they are challenging the "traditional" four-year college concept.

Around the United States, schools are helping to change the way that society views vocational careers, with the growing emergence of schools dedicated towards finding a vocational career. By instilling pride in students early on for learning a trade, vocational-focused schools are shaping the concept that a person does not have to have to attend a four-year school to have a "career." A vocational career is another alternative, and one that takes a student who has as much dedication, determination, drive - but maybe not towards a obtaining a business degree, but becoming a highly-demanded welder, brick mason, or a terrazzo floor specialist.

By providing more opportunities for students to be exposed to construction trade careers earlier in their education, there is an increased likelihood that students will follow their interests and pursue careers. Apprenticeship programs and mentors are also extremely valuable and can provide shy students with experience and knowledge to push them not only to learn but to reach their highest potential in their trades.

While the vocational education program has grown significantly, it has only begun its transformation. Based on interviews and data analysis of the availability and interest of vocational programs in schools, one can be sure that America's educational system is embracing this change and supporting industry's need by providing not only more schools, but higher quality schools to help students interested in vocational programs have an opportunity to determine if that is the right fit for them. By overcoming the concept that four year degrees equal "careers," the American school system is changing the public's outlook of the trade careers. Removing this stigma will provide more opportunities for students, and more employees for the industries.

\section{References}

[1] Begue, J. (2017, June 4). Program Director, Construction Management Technology at Cape Fear Community College. (C. Jayroe, Interviewer)

[2] Bigelow, B., Ostadalimakhalbaf, M., \& Escamilla, E. (2016). Factors Impacting Hispanic High School Students and How to Best Reach Them for the Careers in the Construction Industry. International Journal of Construction Education and Research, 16. https://doi.org/10.1080/15578771.2015.1077296

[3] Christine Fiori, P. P. (2003). What's Wrong with Working in Construction? How Image and Diversity Issues are Affecting the Shortage of Skilled Labor . American Society of Civil Engineers Library. https://doi.org/10.1061/40671(2003)3

[4] Code of Federal Regulations. (2017, June 04). Retrieved from https://cfr.vlex.com/vid/61-250-2-what-definitions-apply-this-19781839

[5] DelaCourt, H. (2016, March 30). Technical high school eyes 2017 opening. Wilmington StarNews. Retrieved June 04, 2017, from http://www.starnewsonline.com/news/20160330/technical-high-school-eyes-2017-opening

[6] Goldstein, D. (2012). The Future of Vocational Education. Economic Policy.

[7] H.R.2353 - Strengthening Career and Technical Education for the 21st Century Act. (n.d.). Retrieved June 04, 2017, from United States Congress Legislative Activities, 115 Congress (2017-2018): H.R.2353 - Strengthening Career and Technical Education for the 21st Century Act

[8] Huggett, S. (2017, June 29). 2017 GOAL Student of the Year. (C. Jayroe, Interviewer)

[9] Hyslop, A. (2017, 05 15). Perkins Bill Markup Schedule for May 17. CTE Policy Watch Blog. Retrieved June 4, 2017, from CTE Policy Watch Blog: http://ctepolicywatch.acteonline.org/2017/05/perkins-bill-markup-scheduled-for-may-17.html

[10] Issue Brief Carl D. Perkins Act. (2017, July 15). Retrieved from Council for Exceptional Children: https://www.cec.sped.org/ /media/Files/Policy/Current\%20Sped\%20lssues\%20Home/Perkins.pdf

[11] National Center for Education Statistics. (n.d.). Retrieved June 15, 2017, from Tables: Secondary/High School: https://nces.ed.gov/surveys/ctes/tables/index.asp?LEVEL=SECONDARY

[12] National Center for Education Statistics. (n.d.). Retrieved June 4, 2017, from Tables: Postsecondary/College: rveys/ctes/tables/index.asp?LEVEL=COLLEGE

[13] National Occupational Employment and Wage Estimates United States - May 2016. (2017, March 31). Retrieved June 04, 2017, from Bureau of Labor Statistics: https://www.bls.gov/oes/current/oes_nat.htm\#47-0000

[14] Shan, Ph.D., P.E., M.ASCE, Y., Imran, H., Lewis, Ph.D., P.E., M.ASCE, P., \& Zhai, Ph.D., D. (2017). Investigating the Latent Factors of Quality of Work-Life Affecting Construction Craft Worker Job Satisfaction. American Society of Civil Engineers, 10. https://doi.org/10.1061/(ASCE)CO.1943-7862.0001281

[15] Smith-Hughes Act. (2003). In Dictionary of American History. The Gale Group Inc.

[16] Tables: Post-Secondary/College. (n.d.). Retrieved June 15, 2017, from National Center for Education Statistics: https://nces.ed.gov/surveys/ctes/postsec.asp 
Proceedings of the Creative Construction e-Conference (2020) 022

Available online at e-2020.creative-construction-conference.com/proceedings/

[17] Tables: Secondary/High School. (n.d.). Retrieved June 15, 2017, from National Center for Education Statistics: https://nces.ed.gov/surveys/ctes/tables/index.asp?LEVEL=SECONDARY

[18] The Construction Labor Shortage: Where Did All the Skilled Labor Go? (2017). Tradesman International. Retrieved from The Construction Labor Shortage: Where Did All the Skilled Labor Go?

[19] Uchitelle, L. (2012, July 21). A Nation That's Losing Its Toolbox. The New York Times.

[20] Wake County names new CTE high school and hires its principal. (2016, October 05). The News \& Observer. Retrieved from The News \& Observer.

[21] Wright, J. (2013, March 7). America's Skilled Trades Dilemma: Shortages Loom As Most-In-Demand Group Of Workers Ages. Forbes. 